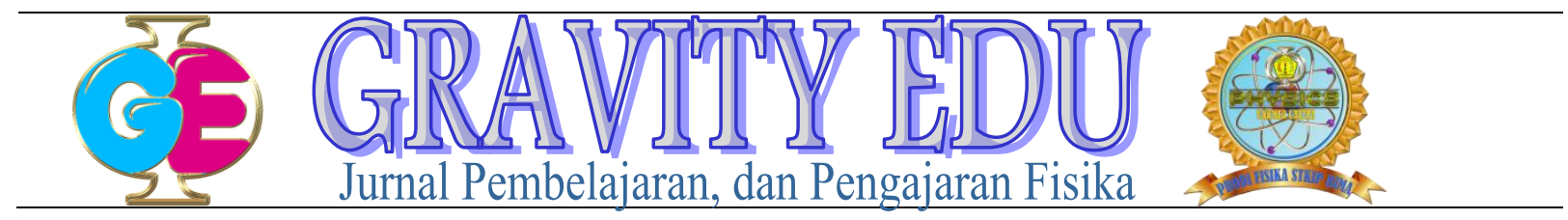

\title{
Rancangan Alat Desinfektan Otomatis Berbasis Mikrokontroler dalam Pencegahan Penyebaran Covid-19
}

\author{
Anarni Wulandari ${ }^{1}$, Yus' iran $^{2}$, Lis Suswati ${ }^{3}$ \\ 1,2,3 Pendidikan Fisika - STKIP Bima \\ Email: ${ }^{1)}$ wulandarianarni@gmail.com \\ 2) yusiranbima@gmail.com \\ 3) finayuli123@gmail.com
}

\begin{abstract}
ABSTRAK : Pada awal masuknya covid di wilayah kota Bima pada bulan maret, terdapat sejumlah orang mengalami gejala covid bahkan ada beberapa orang yang terjangkit positif virus tersebut. Oleh karena perlunya masyarakat diberi informasi salah satu cara untuk memanimalisir penyebaran virus yaitu dengan membuat alat desinfektan otomatis, karena sistem untuk membunuh bakteri, virus, kuman, dan mikroorganisme, salah satunya yaitu COVID-19 yang merupakan penyakit menular oleh sindrom pernapasan akut coronavirus berbahaya lainnya. Alat disinfektan ini otomatis merupakan sebuah cara atau proses penggunaan sebuah mesin, sistem control, atau sebuah teknologi informasi untuk mempermudah masyarakat supaya tidak menyemprot secara manual. Desinfektan adalah cairan pembersih yang umumnya dibuat dari hidrogen peroksida, creosote, atau alkohol yang bertujuan menggunakan sensor ultrasonic HC-SR04 untuk mendeteksi jarak suatu objek dengan control Arduino Uno. Penelitian ini bertujuan untuk membuat rancangan alat disinfektan otomatis berbasis mikrokontroler dalam pencegahan penyebaran Covid-19 di program studi pendidikan fisika. Metode yang digunakan ialah metode eksperimen dimana pengujian alat dan pengambilan data dilakukan dengan cara pengulangan, pada percobaan jarak $10 \mathrm{~cm}$ didapatkan waktu respon selama $0,1 \mathrm{~s}, 0,1 \mathrm{~s}, 0,1 \mathrm{~s}, 0,1 \mathrm{~s}, 0,1 \mathrm{~s}$ dengan nilai debit air $0,022 \mathrm{~L} / \mathrm{s}, 0,024 \mathrm{~L} / \mathrm{s}, 0,02 \mathrm{~L} / \mathrm{s}, 0,018 \mathrm{~L} / \mathrm{s}, 0,021 \mathrm{~L} / \mathrm{s}$ dengan indikator relay dan pompa menyala sebanyak 5 kali. Kinerja pengujian alat menunjukkan bahwa sistem kerja rangkaian alat desinfektan otomatis yang didasarkan objek terhadap manusia yang memiliki sistem input yang terhubung pada Mikrocontroler, sistem yang dimiliki yakni sensor Ultrasonik sebagai input sistem yang otomatis yang bertanggung jawab terhadap pembacaan objek pada saat manusia terdeteksi di depan sensor melalui gelombang Ultrasonik yang dihasilkan objek tersebut. Mikrokontroler mendapat input dari sensor Ultrasonik kemudian akan diteruskan di relay yang menghasilkan output berupa pompa air yang menyala yang akan di semprotkan pada suatu objek. Berdasarkan hasil penelitian jarak $40 \mathrm{~cm}$ dapat dikatakan efektif, karena terdapat standar deviasi waktu ialah 0 dan standar deviasi pada debit air yang rendah. Disarankan dalam merangkai alat, pastikan semua modul dan sensor terpasang dengan benar sesuai dengan program yang dibuat, dan menggunakan pompa yang memiliki tekanan keluaran air yang besar untuk menyemprotkan cairan desinfektan.
\end{abstract}

Kata kunci: Alat desinfektan, COVID-19, sensor ultrasonic HC-SR04

\section{PENDAHULUAN}

Perkembangan ilmu pengetahuan dan teknologi yang sedemikian pesat telah membawa dampak yang cukup besar terhadap kehidupan manusia untuk mempelajari dan mengembangkan ilmu pengetahuannya. Dalam teknologi elektronika dan komputer, efektifitas dan efesiensi selalu menjadi acuan agar setiap langkah dalam penggunaan dan pemanfaatan teknologi diharapkan dapat mencapai hasil yang optimal dalam kualiatas dan kuantitasnya. Seiring dengan majunya pola pikir dari sumber daya manusia sehingga perkembangan teknologi selalu bersesuaian dengan zaman sehingga dapat mengeluarkan ide dan pikiran kreatifnya untuk menyiptakan alat dan hasilnya dapat mempermudah penggunaan masyarakat.
COVID-19 merupakan penyakit menular yang disebabkan oleh sindrom pernapasan akut coronavirus 2 (servere acute respiratory syndrome coronavirus 2 atau SARS-CoV-2). Virus ini merupakan keluarga besar Coronavirus yang dapat menyerang hewan. Ketika menyerang manusia, Coronavirus biasanya menyebabkan penyakit infeksi saluran pernafasan, seperti flu, MERS (Middle East Respiratory syndrome), dan SARS (Severe Acuate Respiratory syndrome). COVID-19 sendiri merupakan coronavirus jenis baru yang ditemukan di Wuhan, Hubei, China pada tahun 2019 [1]. Tanda-tanda terjangkitnya manusia oleh covid-19 diantaranya adalah batuk, demam, serta kesulitan bernafas setelah bepergian dari daerah yang terjangkit corona oleh karena itu 
diperlukan langkah isolasi untuk penangan penyebaran virus [2].

Penyebaran virus corona menjadi salah satu masalah yang serius terhadap dunia pendidikan, dikarenakan siswa mampu menguasai internet, karena pada kondisi ini pemerintah menganjurkan agar belajar di rumah melalui internet/daring. Untuk mengurangi penyebaran covid yang semakin bertambah pemerintah mengeluarkan surat edaran yang berisi perintah untuk mematuhi protokol kesehatan yang berupa 1. Tetap di rumah aja, 2. Memakai masker, 3 . Mencuci tangan dengan air yang mengalir, 4. Jaga jarak , dll. Dan masih banyaknya masyarakat yang tidak mematuhi protocol kesehatan yang dikeluarkan oleh pemerintah setempat

Oleh karena perlunya masyarakat diberi informasi salah satu cara untuk meminimalisir penyebaran virus yaitu dengan membuat alat disinfektan otomatis, karena sistem otomatis merupakan sebuah cara atau proses penggunaan sebuah mesin, sistem control, atau sebuah teknologi informasi untuk mempermudah masyarakat supaya tidak menyemprot secara manual.

Desinfektan adalah cairan pembersih yang umumnya dibuat dari hidrogen peroksida, creosote, atau alcohol yang bertujuan untuk membunuh bakteri, virus, kuman, dan mikroorganisme berbahaya lainnya yang terdapat pada ruangan atau permukaan benda mati. Disinfektan juga mengandung kosentasi biosida yang tinggi, maka dari itu disinfektan lebih efektik dalam membunuh bakteri dan mikroorganisme pada permukaan benda mati apa pun, yang menjadi perantara paparan infeksi virus atau bakteri berbahaya bila dihirup atau disentuh manusia.

Tujuan penelitian ini yaitu untuk membuat rancangan alat desinfektan otomatis berbasis mikrokontroler dalam pencegahan penyebaran Covid-19 dan memudahkan petugas dalam penyemprotan desinfektan, sehingga petugas tidak perlu lagi melakukan penyemprotan secara manual.

Arduino Uno adalah sebuah board mikrokontroler yang didasarkan pada ATmega 238. Arduino Uno mempunyai 14 pin digital input/output ( 6 diantaranya dapat digunakan sebagai output PWM), 6 input analog, sebuah osilator Kristal $16 \mathrm{MHz}$, sebuah koneksi USB, sebuah power jack, sebuah ICSP header, dan sebuah tombol reset. Arduino Uno memuat semua yang dibutuhkan untuk menunjang mikrokontroler, mudah menghubungkan ke sebuah komputer dengan sebuah kabel USB ataumensuplainya dengan adaptor AC ke DC atau menggunakan baterai untuk memulainya [3].

Sensor Ultrasonik HC-SRO4 adalah sebuah sensor yang berfungsi untuk mengubah besaran bunyi menjadi besaran listrik dan sebaliknya. Disebut Sensor Ultrasonik karena memancarkan gelombang ultrasonic, Umumnya berfrekuinsi $40 \mathrm{KHz}$ dan hanya dapat didengar oleh hewan salah satunya kelelawar. Cara kerjarnya dengan prinsip pantul satu gelombang suara dapat dipakai untuk menafsisrkan eksistensi atau jarak suatu benda dengan frekuensi tertentu. Sensor Ultrasonik HC-SR sebuah modul device transmitter dan receiver ultrasonic memiliki empat pin yaitu VCC, TRIG. ECHO, GND [4].

Relay adalah saklar (switch) yang dioperassikan secara listrik dan merupakan dan merupakan komponen Electromechanical yang terdiri dari dua bagian utama yakni Elektromagnet (coil) dan Mekanikal (Seperangkat Kontak Saklar/ switch). Relay menggunkan prinsip Elektromagnetik untuk menggerakan kontak saklar sehingga dengan arus listrik yang kecil(low power) dapat menghantarkan listrik yang bertegangan lebih tinggi [5].

Mikrokontroler merupakan suatu IC yang di dalamnya berisi CPU, ROM, RAM, dan I/O. Dengan adanya CPU tersebut maka mikrokontroler dapat melakukan proses berfikir berdasarkan program yang telah diberikan kepadanya. Mikrokontroler banyak terdapat pada peralatan elekronik yang serba otomatis, mesin fax dan peralatan elektronik lainnya [6].

\section{METODE PENELITIAN}

Penelitian ini menggunakan Metode eksperimen mengambil data dari datasheet komponen, serta refrensi jarak suatu objek. Metode eksperimen adalah suatu penelitian yang dengan sengaja peneliti melakukan manipulasi terhadap satu atau lebih variabel dengan suatu cara tertentu sehingga berpengaruh pada satu atau lebih variabel lain yang di ukur [7]. Tahapan penelitian yang digunakan untuk merancang alat ini yaitu: Identifikasi dan batasan masalah, data yang diperlukan, konsep, desain, pengumpulan bahan, perakitan, pengujian, simpul dan saran.

\section{Rancangan Penelitian}

Perancangan hardware prototype alat disinfektan otomatis ini, dapat dilihat pada Gambar 1. Catu daya atau power supply $12 \mathrm{~V}$ untuk men-supply Arduino Uno dan Pompa Air. Input arduino berupa sensor ultrasonic HCSR04, sedangkan output arduino berupa relay modul, dimana kontak common dan kontak $N O$ (normali open) sebagai saklar terhubunng ke Pompa Air. Pompa air input menuju ke tampungan cairan disinfektan dan saluran output menuju selang dan sprayer untuk menyemprotkan cairan disinfektan dengan lembut atau berkabut. 


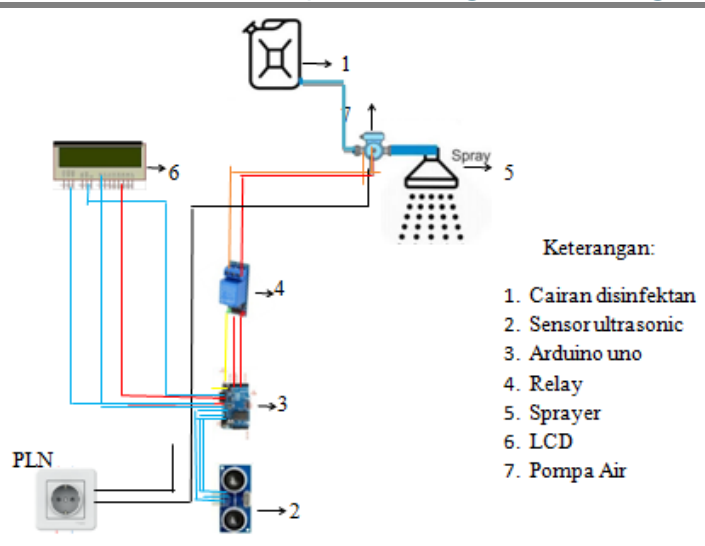

Gambar 1. Desain Hardware alat desinfektan

\section{Alur Program Sistem}

Alur kerja program alat desinfektan otomatis digambarkan dalam desain Prototype dibawah ini. Pembuatan alat desinfektan otomatis mengacu pada alur kerja sistem denga maksudnya sebagai gambaran dari program yang akan dibuat.

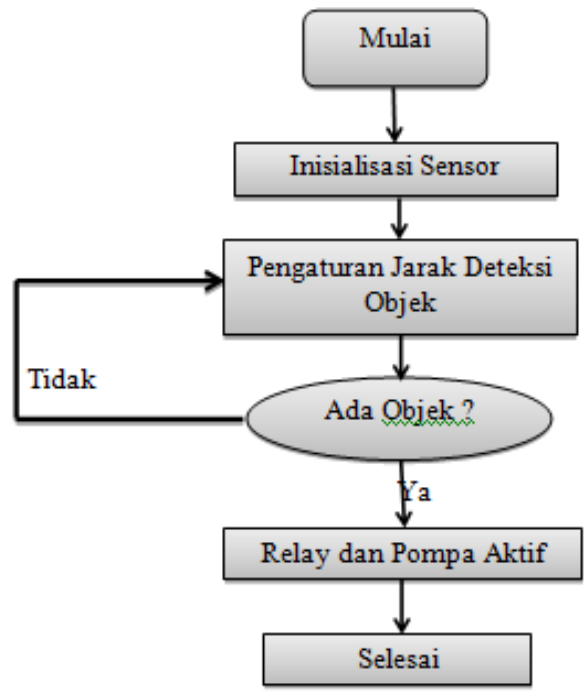

Gambar 2. Flowchart alat disinfektan otomatis

Berdasarkan flowchart di atas, saat alat dihidupkan sensor menginisialisasi mendeteksi objek dalam jangkauannya. Ketika ada objek yang terdeteksi maka sensor akan mengrim sinyak ke arduino, kemudian mengaktifkan relai dan pompa, $L C D$ akan menampilkan jarak suatu benda, sebaliknya jika tidak mendeteksi objek maka posisi alat stanby dan relai off dan $L C D$ akan menampilkan jarak suatu objek.

\section{Tehnik Pengumpulan Data}

Teknik analisis data bertujuan untuk menguraikan dan memecahkan masalah yang berdasarkan data yang diperolah. Analisis yang digunakan adalah analisis kuantitatif.

\section{HASIL DAN PEMBAHASAN \\ Perancangan Alat Penelitian}

Rancangan alat disinfektan otomatis diinput sensor ultrasonik sebagai pendeteksi suatu objek. Pada sensor ultrasonic pin VCC disambungkan ke sumber tegangan papan arduino 5 volt, GND ke pin GND arduino, ECHO ke pin 11 Arduino, TRIGPIN ke pin 10 arduino. LCD pin RS terhubung ke pin 2 arduino, En ke pin 3 arduino, D4 ke pin 4 arduino, D5 ke pin 5 arduino, D6 ke pin 6 arduino, D7 ke pin 7 arduino, Relay kaki pin VCC ke papan rangkaian, GND ke papan rangkaian, Kaki pin IN ke pin 8 arduino, Pompa air terhubung ke relay NO dan COM.

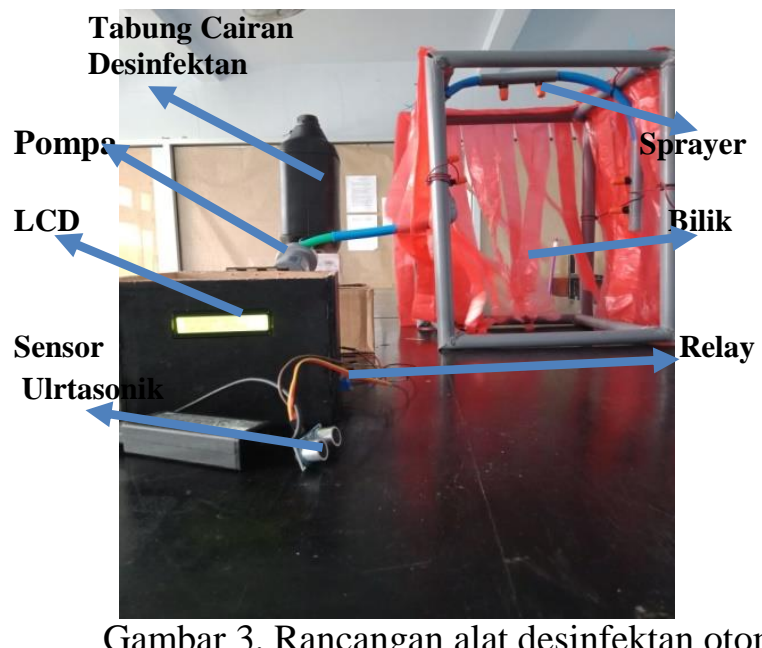

Gambar 3. Rancangan alat desinfektan otomatis

\section{Data Hasil Penelitian dan Pembahasan}

Tabel 1. Hasil Perhitungan Waktu Kepekaan Sensor

\begin{tabular}{|c|c|c|c|c|c|c|c|c|c|c|}
\hline \multirow{2}{*}{ No } & \multirow{2}{*}{ Jarak $(\mathrm{cm})$} & \multicolumn{5}{|c|}{ Waktu(s) } & \multirow{2}{*}{$\begin{array}{l}\text { Rata- } \\
\text { rata }\end{array}$} & \multirow{2}{*}{ Std } & Kriteria & Indikator \\
\hline & & Per 1 & Per 2 & Per 3 & Per 4 & Per 5 & & & \multirow{6}{*}{$\begin{array}{l}\text { Deteks } \\
\text { objek, } \\
\text { indikator } \\
\text { relaydan } \\
\text { pompa On }\end{array}$} & 5 relay $0 \mathrm{n}, 5$ pompa $0 \mathrm{n}$ \\
\hline 1 & 10 & 0,1 & 0,1 & 0,1 & 0,1 & 0,1 & 0,1 & 0 & & 5 relay $0 \mathrm{n}, 5$ pompa $0 \mathrm{n}$ \\
\hline 2 & 20 & 0,1 & 0,2 & 0,2 & 0,1 & 0,1 & 0,14 & 0,05477 & & 5 relay $0 \mathrm{n}, 5$ pompa $0 \mathrm{n}$ \\
\hline 3 & 30 & 0,2 & 0,2 & 0,1 & 0,1 & 0,1 & 0,14 & 0,05477 & & 5 relay $0 \mathrm{n}, 5$ pompa 0 n \\
\hline 4 & 40 & 0,2 & 0,2 & 0,2 & 0,2 & 0,2 & 0,2 & 0 & & 5 relay $0 \mathrm{n}, 5$ pompa $0 \mathrm{n}$ \\
\hline 5 & 50 & 0,2 & 0,2 & 0,2 & 0,2 & 0,3 & 0,22 & 0,04472 & & 5 relay $0 n, 5$ pompa 0 n \\
\hline
\end{tabular}

Tabel 2. Hasil Perhitungan Jumlah Debit Air

\begin{tabular}{|c|c|c|c|c|c|c|c|c|}
\hline \multirow{2}{*}{ No } & \multirow{2}{*}{ Jarak (cm) } & \multicolumn{5}{|c|}{ Debit Air } & \multirow{2}{*}{$\begin{array}{c}\text { Rata- } \\
\text { rata }\end{array}$} & \multirow{2}{*}{ Std } \\
\cline { 3 - 8 } & & Per 1 & Per 2 & Per 3 & Per 4 & Per 5 & & \\
\hline 1 & 10 & 0,022 & 0,024 & 0,02 & 0,018 & 0,018 & 0,0204 & 0,00261 \\
\hline 2 & 20 & 0,02 & 0,018 & 0,021 & 0,024 & 0,024 & 0,0214 & 0,00261 \\
\hline 3 & 30 & 0,022 & 0,021 & 0,022 & 0,024 & 0,024 & 0,0226 & 0,00134 \\
\hline 4 & 40 & 0,021 & 0,024 & 0,022 & 0,024 & 0,024 & 0,023 & 0,00141 \\
\hline 5 & 50 & 0,024 & 0,022 & 0,022 & 0,02 & 0,02 & 0,0216 & 0,00167 \\
\hline
\end{tabular}

Dari tabel 1 dan tabel 2 didapatkan nilai waktu respon dan nilai debit air untuk sensor ultrasonic. Pada sensor ultrasonic pengujian alat dan pengambilan data dilakukan pengulangan sebanyak 5 kali pada percobaan jarak $10 \mathrm{~cm}$ didapatkan waktu respon selama $0,1 \mathrm{~s}, 0,1 \mathrm{~s}, 0,1 \mathrm{~s}, 0,1 \mathrm{~s}, 0,1 \mathrm{~s}$ dengan nilai debit air $0,022 \mathrm{~L} / \mathrm{s}, 0,024 \mathrm{~L} / \mathrm{s}, 0,02 \mathrm{~L} / \mathrm{s}, 0,018$ $\mathrm{L} / \mathrm{s}, 0,021 \mathrm{~L} / \mathrm{s}$ dengan indikator relay dan pompa menyala sebanyak 5 kali, pada percobaan jarak $20 \mathrm{~cm}$ didapat waktu 
respon selama $0,1 \mathrm{~s}, 0,2 \mathrm{~s}, 0,2 \mathrm{~s}, 0,1 \mathrm{~s}, 0,1 \mathrm{~s}$ dengan nilai ratarata debit air $0,02 \mathrm{~L} / \mathrm{s}, 0,018 \mathrm{~L} / \mathrm{s}, 0,021 \mathrm{~L} / \mathrm{s}, 0,024 \mathrm{~L} / \mathrm{s}$, $0,021 \mathrm{~L} / \mathrm{s}$ dengan indikator relay dan pompa menyala sebanyak 5 kali, pada percobaan jarak $30 \mathrm{~cm}$ didapatkan waktu respon selama $0,2 \mathrm{~s}, 0,2 \mathrm{~s}, 0,1 \mathrm{~s}, 0,1 \mathrm{~s}, 0,1 \mathrm{~s}$ dengan nilai rata-rata debit air $0,022 \mathrm{~L} / \mathrm{s}, 0,021 \mathrm{~L} / \mathrm{s}, 0,022 \mathrm{~L} / \mathrm{s}$, $0,024 \mathrm{~L} / \mathrm{s}, 0,024 \mathrm{~L} / \mathrm{s}$ dengan indikator relay dan pompa menyala sebanyak $5 \mathrm{kali}$, pada percobaan jarak $40 \mathrm{~cm}$ didapatkan waktu respon selama $0,2 \mathrm{~s}, 0,2 \mathrm{~s}, 0,2 \mathrm{~s}, 0,2 \mathrm{~s}, 0,2 \mathrm{~s}$ dengan nilai rata-rata debit air $0,021 \mathrm{~L} / \mathrm{s}, 0,024 \mathrm{~L} / \mathrm{s}, 0,022$ $\mathrm{L} / \mathrm{s}, 0,024 \mathrm{~L} / \mathrm{s}, 0,024 \mathrm{~L} / \mathrm{s}$ dengan indikator relay dan pompa menyala sebanyak $5 \mathrm{kali}$, pada percobaan jarak $50 \mathrm{~cm}$ didapatkan waktu respon selama $0,2 \mathrm{~s}, 0,2 \mathrm{~s}, 0,2 \mathrm{~s}, 0,2 \mathrm{~s}, 0,3 \mathrm{~s}$ dengan nilai rata-rata debit air $0,024 \mathrm{~L} / \mathrm{s}, 0,022 \mathrm{~L} / \mathrm{s}, 0,022$ $\mathrm{L} / \mathrm{s}, 0,02 \mathrm{~L} / \mathrm{s}, 0,02 \mathrm{~L} / \mathrm{s}$ dengan indikator relay dan pompa menyala sebanyak 5 kali.

Adapun yang mempengaruhi waktu kepekaan sensor yang tidak beraturan adalah suhu dan angin yang dapat mempengaruhi pancaran gelombang ultrasonik suatu objek yang berada didepan sensor.

Dari 5 kali percobaan menggunakan sensor ultrasonic yang dilakukan peneliti didapatkan beberapa nilai rata-rata dan nilai deviasi dari waktu dan jumlah debit air, pada percobaan dengan jarak $10 \mathrm{~cm}$ nilai rata-rata dan nilai deviasi yang diperoleh waktu sebesar 0,1 dan 0 sedangkan nilai rata-rata dan nilai deviasi jumlah debit air diperoleh sebesar 0,021 dan 0,00224, pada jarak $20 \mathrm{~cm}$ nilai rata-rata dan nilai deviasi yang diperoleh waktu sebesar 0,14 dan 0,0548, sedangkan nilai rata-rata dan nilai deviasi jumlah debit air diperoleh sebesar 0,0208 dan 0,00217, pada jarak $30 \mathrm{~cm}$ nilai rata-rata dan nilai deviasi yang diperoleh waktu sebesar 0,14 dan 0,548, sedangkan nilai rata-rata dan nilai deviasi jumlah debit air diperoleh sebesar 0,0226 dan 0,00134, pada jarak $40 \mathrm{~cm}$ nilai rata-rata dan nilai deviasi yang diperoleh waktu sebesar 0,2 dan 0 , sedangkan nilai rata-rata dan nilai deviasi jumlah debit air diperoleh 0,023 dan 0,00141 , pada jarak $50 \mathrm{~cm}$ nilai rata-rata dan nilai deviasi yang diperoleh waktu sebesar 0,22 dan 0,0447, sedangkan nilai rata-rata dan nilai deviasi jumlah debit air sebesar 0,0216 dan 0,00167.

\section{KESIMPULAN}

Hasil pengujian pembuatan alat menunjukkan bahwa sistem kerja rangkaian alat desinfektan otomatis yang didasarkan objek terhadap manusia yang memiliki sistem input yang terhubung pada Mikrokontroler, sistem yang dimiliki yakni sensor Ultrasonik sebagai input sistem yang otomatis yang bertanggung jawab terhadap pembacaan objek pada saat manusia terdeteksi di depan sensor melalui gelombang Ultrasonik yang dihasilkan objek tersebut. Mikrokontroler mendapat input dari sensor Ultrasonik kemudian akan diteruskan di relay yang menghasilkan output berupa pompa air yang menyala yang akan di semprotkan pada suatu objek. Berdasarkan hasil penelitian jarak $40 \mathrm{~cm}$ dapat dikatakan efektif, karena terdapat standar deviasi waktu adalah 0 dan standar deviasi pada debit air yang rendah.

\section{UCAPAN TERIMAKASIH}

Terimakasih kepada program studi pendidikan fisika yang telah memberikan fasilitas laboratorium sebagai wahana melakukan uji alat selama proses penelitian berlagsung.

\section{DAFTAR PUSTAKA}

[1] Ilmiyah, S. dkk (2020). Suratul Ilmiyah PBNU Menjawab Tantangan Virus Corona. Dipetik Juni 26, 2020, dari YouTube alobatnic; https://youtu.be/SPdc4WT8BCg

[2] Yuliana. (2020). Corona virus disiases (Covid19); sebuah tinjauan literature. Wallness and healthy Magazine.

https://wallness.journalpress.id/wallness/article/vi ew/21026. Di akses 26 Juni, 2020

[3] Andi Adriyansah, Oka Hidyatama, (2013). Rancangan Bangun Prototipe Elevator Menggunakan Mikrocontroller Arduino Atmega 328p. Jurnal Teknologi Elektro, Universitas Mercu. Vol. 4 No. 3

[4] Iteastudio. (2010). Datasheetyhcsr04., https://imall.iteastudio.com/images/8161s.pdf. Di akses 27 Juni 2020.

[5] Adi Nova Trisetiyanto. (2020). Rancang Bangun Alat Penyemprot Disinfektan Otomatis Untuk Penyegahan Penyebaran Virus Corona. Joined Journal of information education. Vol.3. No.1

[6] Adam Faroqi, Eko. P. H. , Deny Kurnia Halim, dkk.(2016).Perancangan Alat Pendeteksi Kadar Polusi Udara Menggunakan Sensor Gas MQ-7 Dengan Teknologi Wireless Hc-05. Edisi Juli 2016, Volume X, No.2

[7] Arboleda, Cora R. 1981. Communications Research.Manila: CFA 